This Journal is available in Telkom University online Journals

Jurnal Manajemen Indonesia

\title{
Taxpayer Attitude on the Elimination of Tax Sanction and Taxation Awareness toward Taxpayer Compliance in Yogyakarta
}

Suparna Wijaya

Politeknik Keuangan Negara STAN

\begin{abstract}
The impact of tax on state revenue is very dominant these days. This happens because tax is a definite source in contributing funds to the state. Basically, it is a reflection of the mutual cooperation of the community in state financing regulated by legislation. One of the factors causing low taxpayer's compliance takes place because the public as taxpayers forget or maybe even simply ignore their obligation to pay taxes, especially personal income tax. This research is quantitative in nature, which involves testing hypotheses (explanatory). The population in this study is individual taxpayer registered at the Regional Office of the Directorate General of Taxes of the Special Region of Yogyakarta. Approximately 350,935 Individual Taxpayers at the end of 2015 were registered. The research results indicated a positive influence between the attitude of taxpayers and taxpayer's compliance. By contrast, with respect to taxpayer compliance, the analysis on tax elimination variable shows that there is no positive influence between the elimination of tax sanctions and taxpayer compliance. The analysis on tax awareness toward taxpayer compliance indicates a positive influence between tax awareness and taxpayer compliance.
\end{abstract}

Keywords-Tax Awareness; Taxpayer Compliance; Individual Taxpayers; Taxpayer Attitudes.

\begin{abstract}
Abstrak
Perananpajakterhadap pendapatan Negara sangat dominan pada masa sekarang ini.Ini terjadi karena pajak adalah sumber yang pasti dalam memberikan kontribusi dana kepada Negara karena merupakan cerminan dari kegotongroyongan masyarakatdalam pembiayaan negara yang diatur oleh perundang-undangan. Salah satu factor menyebabkan penerimaan pajak yang sulit tercapai yaitu kepatuhan wajib pajak yang rendah itu dibuktikan karena masyarakat selaku wajib pajak lupa, atau bahkan mungkin mengabaikan kewajibannya untuk membayar pajak, khususnya pajak penghasilan orang pribadi. Jenis penelitian ini merupakan penelitian kuantitatif dengan melakukan pengujian hipotesis (eksplanatory). Populasi dalam penelitian ini adalah Wajib Pajak Orang Pribadi yang terdaftar pada Kantor Wilayah Direktorat Jenderal Pajak Daerah Istimewa Yogyakarta, kurang lebih berjumlah 350.935 Wajib Pajak Orang Pribadi pada akhir tahun 2015. Hasil penelitian menunjukkan terdapat pengaruh yang positif antara Sikap wajib pajak dengan kepatuhan wajibpajak, sedangkan untuk variable kepatuhan wajib pajak terhadap penghapusan pajak menunjukkan tidak terdapat pengaruh positif antara penghapusan sanksi pajak dengan kepatuhan wajib pajak dan untuk variable kesadaran perpajakan terhadap kepatuhan wajib pajak menunjukkan terdapat pengaruh positif antara kesadaran perpajakan dengan kepatuhan wajib pajak.
\end{abstract}

Kata kunci—Kesadaran Perpajakan; Kepatuhan Wajib Pajak; Wajib Pajak Orang Pribadi; Sikap Wajib Pajak.

\section{INTRODUCTION}

Every country needs large funds for national development to improve people's welfare. Therefore, it is necessary to increase state revenue from year to year. Indonesian state revenue is regulated in the Law of the Republic of Indonesia Number 17 of 2003, concerning State Finance, as outlined in the State Budget (APBN). State revenues are divided into two, namely tax revenues and non-tax state revenues. Tax revenues are the main

\section{Article info}

Received (16 $6^{\text {th }}$ November, 2018)

Revised (30 ${ }^{\text {th }}$ November, 2018)

Accepted (11 $1^{\text {th }}$ February, 2019)

Corresponding author:sprnwijaya@gmail.com 
source of potential funds that dominate Indonesia's state revenue, comprising of $70 \%$ of the state budget revenues.

The role of tax on state revenue is very dominant, to date. This happens because tax is a definite source in contributing funds to the state because it is a reflection of the mutual cooperation of the community in state financing regulated by legislation. From the APBN data, it is clear that the developing role of tax in APBN is very phenomenal. The 2010 state budget relied more on oil and gas sector revenues, and project assistance increasingly has shifted to enhancing tax revenues in the 2011 fiscal year. This has been evident up until 2016. The data is presented in Table 1 .

Table 1.Achievement of National Revenue (in Billions of Rupiahs) 2010-2016

\begin{tabular}{|c|c|c|c|c|c|c|c|c|}
\hline $\begin{array}{l}\text { Sources } \\
\text { Revenue }\end{array}$ & of & 2010 & 2011 & 2012 & 2013 & 2014 & 2015 & 2016 \\
\hline \multicolumn{2}{|c|}{ National Revenu } & 992249,00 & 1205346,00 & 1332322,90 & 1432058,60 & 1545456,30 & 1496047,33 & 1784249,90 \\
\hline \multicolumn{2}{|c|}{ Tax Revenua } & 723307,00 & 873874,00 & 980518,10 & 1077306,70 & 1146865,80 & 1240418,86 & 1539166,20 \\
\hline \multirow[t]{8}{*}{ National Tax } & & 694392,00 & 819752,00 & 930861,80 & 1029850,00 & 1103217,60 & 1205478,89 & 1503294,70 \\
\hline & $\begin{array}{l}\text { Income } \\
\text { tax }\end{array}$ & 357045,00 & 431122,00 & 465069,60 & 506442,80 & 546180,90 & 602308,13 & 855842,70 \\
\hline & $\begin{array}{l}\text { Value- } \\
\text { added tax }\end{array}$ & 230605,00 & 277800,00 & 337584,60 & 384713,50 & 409181,60 & 423710,82 & 474235,30 \\
\hline & $\begin{array}{l}\text { Land and } \\
\text { house tax }\end{array}$ & 28581,00 & 29893,00 & 28968,90 & 25304,60 & 23476,20 & 29250,05 & 17710,60 \\
\hline & $\begin{array}{l}\text { Purchase } \\
\text { Right on }\end{array}$ & & & & & & & \\
\hline & $\begin{array}{l}\text { Land and } \\
\text { Buildings }\end{array}$ & 8026 & -1 & 0 & 0 & 0 & 0 & 0 \\
\hline & Taxes & 66166,00 & 77010,00 & 95027,90 & 108452,00 & 118085,50 & 144641,30 & 148091,20 \\
\hline & $\begin{array}{l}\text { Other } \\
\text { taxes }\end{array}$ & 3969,00 & 3928,00 & 4210,90 & 4937,10 & 6293,40 & 5568,30 & 7414,90 \\
\hline \multicolumn{2}{|c|}{ International Trade Tax } & 28915,00 & 54122,00 & 49656,30 & 47456,60 & 43648,10 & 34939,97 & 35871,50 \\
\hline & $\begin{array}{l}\text { Import } \\
\text { tax }\end{array}$ & 20017,00 & 25266,00 & 28418,40 & 31621,30 & 32319,10 & 31212,82 & 33371,50 \\
\hline & $\begin{array}{l}\text { Export } \\
\text { tax }\end{array}$ & 8898,00 & 28856,00 & 21237,90 & 15835,40 & 11329,00 & 3727,15 & 2500,00 \\
\hline \multicolumn{2}{|c|}{ Non-tax revenue } & 268942,00 & 331472,00 & 351804,70 & 354751,90 & 398590,50 & 255628,48 & 245083,60 \\
\hline & $\begin{array}{l}\text { from } \\
\text { Natural } \\
\text { Resource } \\
\text { State- }\end{array}$ & 168825,00 & 213823,00 & 225844,00 & 226406,20 & 240848,30 & 100971,87 & 90524,30 \\
\hline & $\begin{array}{l}\text { owned } \\
\text { Company } \\
\text { Revenue } \\
\text { Other }\end{array}$ & 30097,00 & 28184,00 & 30798,00 & 34025,60 & 40314,40 & 37643,72 & 34164,00 \\
\hline & $\begin{array}{l}\text { Non-tax } \\
\text { revenues }\end{array}$ & 59429,00 & 69361,00 & 73458,50 & 69671,90 & 87746,80 & 81697,43 & 84124,00 \\
\hline & $\begin{array}{l}\text { Public } \\
\text { Service } \\
\text { Institution } \\
\text { revenue }\end{array}$ & 10591,00 & 20104,00 & 21704,30 & 24648,20 & 29681,00 & 35315,46 & 36271,20 \\
\hline \multicolumn{2}{|l|}{ Grant } & 3023,00 & 5253,90 & 5786,70 & 6832,50 & 5034,50 & 11973,04 & 1975,20 \\
\hline \multicolumn{2}{|l|}{ Total } & 995271,50 & 1210599,70 & 1338109,60 & 1438891,10 & 1550490,80 & 1508020,37 & 1786225,00 \\
\hline
\end{tabular}

(Source: Bank of Indonesia, 2016)

Tax revenue in the medium term remains the main source of state revenue with an average contribution of $86.1 \%$ of total state revenues. Meanwhile, PNBP contributed an average of 13.9 percent, while grant income contributed an average of 0.01 percent. As the main source of state revenue, government continues to increase tax revenue growth beyond nominal GDP growth.

It appears that the fulcrum of state revenues shifts to tax revenue. Even the role of tax has been on the rise every year. Even in the last few years the government has been very focused on the role of tax in financing the state budget. This is indicated by the increasing tax revenue target by the Director General of Taxes. However, unfortunately there are obstacles that occur in meeting the tax revenue target by the Director General of Taxes 
(DGT). The constraint lies in the form of a tax ratio (which is the amount of tax that is successfully collected compared to the low Gross Domestic Product).

The Directorate General of Taxes launched 2015 as the Year of Taxpayer Development (TPWP 2015) with the motto of Reach the Unreachable, Touch the Untouchable. Through the 2015 Taxpayer Development Year, the Directorate General of Taxes (DGT) called on all levels of society, who have fulfilled subjective and objective requirements in accordance with the provisions of taxation laws based on the Self-Assessment System, to register as a Taxpayer, as well as to obtain a NPWP, in order to avoid criminal sanctions (Ditjen Pajak, 2015). People who fulfill tax obligations, that is becoming a new taxpayer, through PMK No. 91/PMK.03/2015, will be free from administrative sanctions. Administrative sanctions in this regard are sanctions that arise due to delays in submitting a Notice of Return (SPT) or late payment of tax. This policy is expected to increase the level of taxpayer compliance in NPWP registration.

One of the factors causing tax revenues is difficult to achieve, namely low taxpayer compliance is evidenced because the public, as taxpayers, forget or possibly even ignore their obligation to pay taxes, especially personal income tax. This $\mathrm{I}$ is even the case especially in the midst of changing people's views on all aspects of governance, as well as various situations that arise and lead to negative impression regarding taxation issues (Fikri, 2012).

Although the number of taxpayers throughout the years has been increasing, there are obstacles that can hamper efforts to increase the tax ratio. These constraints are tax compliance. Jamin (2001) directly states that it is necessary to increase tax compliance in order to increase the tax ratio. Based on research by Jamin (2001), it is also acknowledged that the level of corporate taxpayer compliance (WP Agency) and individual taxpayers (WP OP) turned out to be higher levels of corporate taxpayer compliance.

In addition, the taxpayer is accorded with the elimination of administrative sanctions in the form of interest of $2 \%$ per month for the delay in repayment of the lack of tax payments, thus enabling them to avoid tax audits. This policy is known as the Sunset Policy. This term is used to describe government short-term policies, within the context of a public policy. This policy, which is limited to the validity period, marks the outset of the term Sunset Policy.

This study investigated the level of compliance of OP WP in the city of Yogyakarta. This research was conducted in Yogyakarta because based on data from KPP in the city of Yogyakarta it was found out that the level of taxpayer compliance was ranked second at the national level. According to Pramudito, in 2015, a year of tax coaching, the level of tax compliance in DIY was very encouraging, ranking second in Indonesia in the Directorate General of Taxes (73.7\%), exceeding the expected target (72.5\%). This, he furthered, could not be separated from the increased awareness of taxpayers, the support of the local government, the mass media, stakeholders and the public who helped secure tax revenue.

While the Governor of DIY in his remarks said that 2015, which was designated as the year of tax coaching, could be interpreted as a year to build mutual trust between tax authorities and taxpayers. The strategy to increase compliance through tax audits have resulted in no significant effect, as evinced by the Director General of Taxes. This is because up until now the tax ratio has remained around $10 \%$ (now 11\%). As such, then the Governor clearly states that "the best solution is to foster mutual trust and openness, treat taxpayers with excellent service but also proved by honesty from taxpayers".

For this reason, the problem worth investigation is pertinent to the number of taxpayers who avoid taxes. Therefore, research on factors that influence the compliance of individual taxpayers who conduct business activities and free work in Yogyakarta is very necessary. Back grounded by this issue, this study seeks to discuss the attitude of taxpayers on the elimination of tax sanctions, and tax awareness of personal taxpayer compliance in the city of Yogyakarta.

\section{LITERATUREREVIEW}

\section{A. Understanding of Tax}

Many experts in the field of taxation provide different definitions of tax, but in essence the $y$ have the same meaning. The following are some tax definition citations, including the following. Supriyanto (2011:1) points out that: 
Tax is a mandatory contribution or levy collected by the government from the community (taxpayers) to cover state's regular expenditures and development costs without remuneration that can be directly appointed. In the same vein, Sumardiyanti and Suryo (2006:3) define tax as the following:

Tax is a contribution in the form of money (not goods) collected by the government (state) with a certain regulation (certain tariff), which is then used for financing the public interest.

\section{B. The Definitions of tax compliance}

According to Gunadi (2005), the notion of tax compliance relates to the extent to which taxpayers have the willingness to fulfill their tax obligations in accordance with the applicable rules without the need to conduct examinations, thorough investigations, warnings or threats, in the application of both legal and administrative sanctions. Nurmantu, (2003) defines tax compliance as a condition where taxpayers fulfill all tax obligations and carry out their taxation rights.

Compliance, according to Norman D. Nowak, is defined as a "climate" of compliance and awareness of fulfillment of tax obligations reflected in the following circumstances (Devano in Supadmi, 2010).

a) Understanding or try to understand all provisions of taxation legislation.

b) Completing the tax form completely and clearly.

c) Calculating the amount of tax owed correctly.

d) Paying taxes payable on time.

\section{Sunset Policy}

Sunset Policy is a tax facility regulated under Article 37A of Law No. 28/2007 concerning General Provisions and Procedures for Taxation. This facility allows an individual taxpayer or an entity to correct the income tax return $(\mathrm{PPh})$ in the 2007 tax year and the previous year, without being entitled to administrative sanctions. Historically, the Sunset Policy was actually issued as a response to the government which required businessmen who wanted to give a complete abolition of taxation s anctions. That is, the subject of the Sunset Policy is that taxpayers who are not compliant or have not fulfilled their tax obligations properly, so they will correct the tax return correctly. However, in its implementation, Sunset Policy was then used as an instrument by the Director General of Taxes to expand and strengthen the basis of national tax.

\section{Effect of Taxpayer Awareness on Taxpayer Compliance}

Awareness is an element in humans to understand reality and how they act or behave towards reality. Jatmiko (2006) explains that awareness is a state of knowing or understanding. Irianto (2005) in Widayati and Nurlis (2010) describes some forms of awareness to pay taxes that encourage taxpayers to pay taxes. First, awareness represents a form of participation in supporting the development of the country. Knowing this, taxpayers want to pay taxes because they are not harmed from tax collection. Second, awareness which is manifest delaying tax payments and reducing tax burdens is very detrimental to the state. Within this regard, taxpayers want to pay taxes because they understand that late payment of taxes and reduction of the impact of tax burden on lack of financial resources, which can cause delays in the development of the country. Third, awareness defines that taxes are set by law and can be enforced. Taxpayers will pay for tax payments have realized a strong legal basis and are an absolute obligation of every citizen.

\section{E. Personal Taxpayer}

Individual taxpayers who conduct business activities or independent work are those who conduct business activities and are not bound to an employer. The definition of running a business activity in question refers to any business across various fields, be it agriculture, industry, trade, and so on. By contrast, freelance is ge nerally related to the expertise or profession carried out by experts. These include lawyers, accountants, consultants, notaries, or doctors. That is to say, the perpetrators of freelance open their own establishment with their own names. If the person concerned only works or has an employment status at a company. For example an accountant works in a Public Accountant Office, and then he is not included as an individual taxpayer who carries out free work.

Taxpayer compliance can be defined as a condition where taxpayers fulfill all tax obligations and carry out their taxation rights (Rahman, 2010:32). Personal taxpayer compliance is a condition where an individual taxpayer, who works as an employee or manages his own business, is required to fulfill all of his tax obligations 
and given the rights in accordance with the stipulated tax laws. Compliance with taxation is formal, represented as the compliance with the rights and obligations of taxpayers, procedures, and sanctions in taxation.

According to Rahayu (2010:245), taxpayer compliance is the main objective of a tax audit from which the results of the tax audit will be known as indicated by the level of taxpayer compliance. For taxpayers with low (minimal) compliance, it is expected that the audit provide positive motivation to become better taxpayer in the future.

\section{RESEARCH METHOD}

This research is quantative in nature, which involves testing hypotheses (explanatory study). This study aims to portray the causal relationship between the independent variables, namely the attitude of the taxpayer on the elimination of tax sanctions and the awareness of taxation, on the dependent variables pertinent to personal taxpayer compliance in the city of Yogyakarta.

As stated by Narbuko and Ahmadi (2007:107), the sample is some of the individuals investigated from the entire research individual. Furthermore, Narkubo and Ahmadi explain that no definite criteria apply to determining the size of the sample. The research subjects are determined by using purposive sampling, by which is a sample determined by taking subjects without taking into account subjects' strata. Rather, this method is based on certain goals a researcher aims to achieve (Arikunto, 2005:117).

The research method operative in this study delves into causal relationhip and examines the proposed hypothesis. The analysis technique in the study is path analysis. Path analysis is made operative because the research model consists of independent variables, intervening variables, and dependent variables. As such, us ing the path analysis enables the researcher to examine the variables simultaneously. In testing the hypothesis using path analysis, the approach chosen is almost the same as the SEM approach (Hair et al., 2014)

The population in this study is an the individual taxpayer registered at the Regional Office of the Directorate General of Taxes of the Special Region of Yogyakarta, involving approximately 350,935 Individual Taxpayers by the end of 2015. The following table shows the number of registered individual taxpayers.

Table 2. The Number of Registered Individual Taxpayers in Yogyakarta

\begin{tabular}{ll}
\hline Region & The Number of Registered Taxpayers \\
\hline KPP PratamaSleman & 162.121 \\
KPP PratamaBantul & 98.460 \\
KPP PratamaWates & 43.931 \\
KPP PratamaWonosari & 46.423 \\
Total & 350.935 \\
\hline
\end{tabular}

Source: KPP Pratama in Special Region of Yogyakarta (2015)

The sample is determined by using sampling technique. The sampling technique used for sampling is incidental sampling. This technique is one of the nonprobability sampling techniques where the samples are chosen based on opportunity that is anyone can be used as a sample. That is only possible when the person meets the criteria of research subject (Sugiyono, 2009:85).

\section{RESULT}

\section{A. Data Normality}

After the research instrument was proven valid and reliable, the assumption was tested. The investigation on key assumptions in SEM was the preliminary evaluation criteria (Byrne, 2016). This is the stage where the most crucial key assumption, within the estimation of maximum likelihood (ML), is data normality at the multivariate level. Data normality is considered pivotal in this regard as the violations of multivariate assumptions normal data can cause serious bias in the results of parameters estimation in the model. As such, the results of the analysis may be considered unvalid (Byrne, 2016; Hair et al., 2014). The assumption of data normality is intended to determine whether exogenous variables and endogenous variables are normally distributed or close to normal (Santoso, 2001). Violation of this assumption, according to Kline (2004), also indicates the problem 
of nonlinearity and heteroscedasticity. Therefore, in this study testing the assumption of multivariate normality was carried out at the outset of the study.

In addition, in the measurement model estimated by the maximum likelihood estimation (MLE), the normality of the data in a multivariate manner is an absolute requirement. Violating this assumption will cause a large standard error and a bad goodness of fit index, so the interpretation of the loading factor becomes biased. Multivariate normality is tested through Mardia's Statistic, and the threshold at work is the maximum value of the Mardia's Statistic critical ratio = 3 (Bagozzi \& Baumgartner, 1994). At the univariate level, data normality can be evaluated from skewness (= shows the extent to which data is symmetrically distributed) and kurtosis (= shows data distribution appearances) where the critical ratio for skewness and kurtosis is no more than \pm 2.58 (Bagozzi\& Baumgartner, 1994). Based on the criteria for testing data normality, it was concluded that the data used for exogenous constructs were normally distributed at both the univariate and multivariate levels, as shown in the following table.

Table.3 Data Normality Test Assessment of normality (Group number 1)

\begin{tabular}{ccccccc}
\hline Variable & Min & $\max$ & skew & c.r. & kurtosis & c.r. \\
\hline Taxpayer attitude & 2.000 & 10.000 & .222 & .993 & .204 & .455 \\
Tax sanction & 2.000 & 10.000 & .328 & 1.468 & -.016 & -.036 \\
Taxation awareness & 4.000 & 14.000 & .304 & 1.360 & -.072 & -.160 \\
Taxpayer compliance & 3.000 & 14.000 & .639 & 1.156 & -.227 & -.508 \\
Multivariate & & & & & 9.380 & 2.141 \\
\hline
\end{tabular}

Source: Estimation Result from AMOS21 (2016)

It appears in the table above that there is no univariate skewness value greater than 3 , and none of the univariate kurtosis exceeds 10 as suggested by Kline (2004). This condition is supported by the critical ratio (C.R.) value for skewness and kurtosis for each variable that is not greater than \pm 2.58 . As a result, the data is proven normally distributed at the univariate level (Byrne, 2001). In multivariate kurtosis lines, it appears that the value of C.R. is also not greater than \pm 2.58 , implying that that the data are normally distributed at the multivariate level (Byrne, 2016).

\section{B. Suitability Test and Statistical Test}

Testing of this model uses several fit indices to measure the suitability of the research model being developed. The AMOS 21 analysis generates the following results.

Table 4 Evaluation of Goodness of Fit Index

\begin{tabular}{llll}
\hline Criteria & Model Results & Critical Value & Conclusion \\
\hline Chi-Square & 23.337 & 89.27 & Good \\
Probability & 0,086 & $\geq 0,05$ & Good \\
RMSEA & 0,027 & $\leq 0,08$ & Good \\
GFI & 0,984 & $\geq 0,90$ & Good \\
AGFI & 0,881 & $\geq 0,90$ & Moderate \\
CMIN/DF & 2,453 & $\leq 5,00$ & Good \\
TLI & 0,971 & $\geq 0,95$ & Good \\
NFI & 0,990 & $\geq 0,90$ & Good \\
CFI (Comparative fit & 0,994 & $\geq 0,95$ (Bentler) & Good \\
index) & & &
\end{tabular}

Source: Primary Data, 2016 
Table 4 informs that the model conformity test results indicate a good level of acceptance. Therefore, it can be concluded that the dimensions that make up the variables, be it exogenous or endogenous, are appropriate, and implying that the research model can be accepted.

With regard to the criteria for goodness of fit, the estimated structural models are proven valid. The relationship between constructs in hypotheses is shown by regression weights values (Hair et al, 2014). For more details concerning the influence of cognitive beliefs, emotional trust in buying interest in Giancomputeris presented in Table 5.

Table 5. Regression Weights

\begin{tabular}{|c|c|c|c|c|c|c|c|}
\hline & & & Estimate & S.E. & C.R. & $\mathrm{P}$ & Lable \\
\hline Taxpayer attitude & $<--$ & Taxpayer compliance & .207 & .087 & 2.365 & .018 & par_1 \\
\hline Elimination of Tax sanction & $<--$ & Taxpayer compliance & .438 & .110 & 1.986 & .538 & par_4 \\
\hline Taxation awareness & $<--$ & Taxpayer compliance & .749 & .093 & 8.014 & $* * *$ & par_5 \\
\hline
\end{tabular}

\section{Effect of taxpayer attitudes on taxpayer compliance}

Based on the analysis results, the study indicates that the influence of the taxpayer attitude toward taxpayer compliance is marked by a CR value of 2.365 ( $\mathrm{p}=5$ 0.05). As a result, Ho is rejected, while Ha is accepted, meaning that there is a positive influence between the attitude of the taxpayer with taxpayer compliance. H1 hypothesis, indicating that there is an influence of the taxpayer's attitude towards taxpayer compliance, is approved.

\section{The effect of the elimination of tax sanctions on taxpayer compliance}

Through statistical calculations using SEM Amos 21, the study has revealed that the effect of the elimination of tax sanctions on taxpayer compliance is marked by a CR value of 1,986 ( $p \Rightarrow 0.538$ ). This implies that there is no positive effect between the elimination of tax sanctions and taxpayer compliance. As such, Ho is rejected, while $\mathrm{Ha}$ is accepted. Hypothesis $\mathrm{H} 2$, which presumes that there is no effect of the elimination of tax sanctions on taxpayer compliance, is refused.

\section{E. The Effect of tax awareness on taxpayer compliance}

Through statistical calculations using SEM Amos 21, the study indicates that the effect of taxawareness on taxpayer compliance is marked by a CR value of $8.014(\mathrm{p}=50.05)$, meaning that there is a positive influence between tax awareness and taxpayer compliance. This concludes that Ho is rejected, while Ha is accepted. Hypothesis H3, presuming that there is an effect of taxpayer compliance on taxpayer compliance, is approved.

\section{DISCUSSION}

\section{A. Effect of taxpayerattitudes on taxpayer compliance}

A study by Leba (2016) shows that the abolition of tax sanctions does not have an impact on compliance with registration. This can be seen from the low utilization of the tax elimination policy and the insignificant increase in WPOP numbers. This study als o shows that the abolition of tax sanctions has a positive impact on compliance with tax payments for Annual Income Tax underpayments. This can be seen from the increase in the number of WPOPs who make tax payments on Annual Income Tax underpayment of Income Tax after the implementation of the policy of eliminating tax penalties. Andayu (2015) points out that the experience of taxpayers in carrying out tax obligations, the quality of service of tax officers, and the mass media of taxation affect taxpayer compliance simultaneously. Nastiti (2014) indicates that the attitude of taxpayers and tax knowledge does not significantly influence taxpayer compliance in paying the Land and House tax, as marked by a significance value of 0.877 and 0.702 , respectively. Likewise, when tested simultaneously, the attitude of the taxpayer and knowledge of taxation do not significantly influence taxpayer compliance in paying the Land and House tax, as evinced by a significance value of 0.920 . The compliance of taxpayers in Bany udono village was only evident when village officials or tax authorities collected taxes by visiting the taxpayer's house. According to research by Suyatmin (2004), the taxpayer attitude to regional development priorities, the attitude 
of taxpayer to Land and House tax fines sanctions, the taxpayer attitude to tax authorities' services, the taxpayer attitude to national awareness, and taxpayer attitude towards tax awareness have been proven to significantly influence taxpayer compliance in the city of Surakarta.

\section{B. The effect of the elimination of tax sanctions on taxpayer compliance}

According to the research results by Indah (2016), the abolition of tax sanctions has a positive impact on the compliance of tax payments on Annual Tax Returns for Underpayment of Income Tax. In addition, it also has a positive impact on the increase of tax revenue. This is also supported by Alkautsar's research (2015). The results of this study points out several important concerns. First, the elimination of tax sanctions and taxpayer compliance in reporting annual tax returns together affect tax revenue. Second, elimination of tax sanctions does not affect tax revenue. In addition, taxpayer compliance in reporting annual tax returns affects income tax revenue.

\section{Effect of tax awareness on taxpayer compliance}

The research conducted by Sari (2014) reveal several vital findings. First, the taxpayer awareness has a significant effect on taxpayer compliance. This can be seen based on the results of a correlation test of 0.612 , classified in the strong relationship category. Second, taxation sanctions have a significant effect on compulsory compliance tax, which can be seen from the correlation test result of 0.465 . This categorized as moderate relations. Another finding point out that taxpayer awareness and taxation sanctions have a significant effect on taxpayer compliance, which can be seen from the simultaneous test result of $44.6 \%$. The remaining $55,4 \%$ is influenced by other factors. Febianti (2015) suggests Garut KPP Pratama to increase the awareness of individual taxpayers by providing socialization to individual taxpayers in collaboration with relevant agencies. Moreover, the enactment of laws concerning tax sanctions (fines) can be effective solution to regulating the taxation system. For future researchers, it is recommended that further research encompass a wider scope and objects that are not limited to individual taxpayers. Therefore, research results can be more apt.

\section{CONCLUSION}

Based on the analysis results, the study has drawn the following conclusions. First, the study has revealed that the influence of the attitude of the taxpayer toward taxpayer compliance is marked by a CR value of 2.365 $(\mathrm{p}=5$ 0.05). This means that there is a positive influence between the taxpayer attitude and taxpayer compliance. While the effect of eliminating tax sanctions on taxpayer compliance obtains a CR value of 1,986 ( $\mathrm{p}=>0.538$ ), meaning that there is no positive effect between the elimination of tax sanctions and taxpayer compliance. Lastly, the influence between tax awareness variables on taxpayer compliance to obtain a CR value of 8.014 ( $\mathrm{p}=50.05)$, meaning that there is a positive influence between tax awareness and taxpayer compliance. Finally, there are some recommendations that can be executed based on the conclusions above. Hence, to increase the level of taxpayer compliances, the government, in this case, the Directorate General of Taxes, must pay attention to all matters which can be held to increase the positive attitude of taxpayers and their tax awareness. It can be done by fostering the importance of taxes for the community, conducting publication based on the performance of the tax authorities, enhancing socialization to taxpayers, utilizing technology for taxation applications, and creating an excellent service to taxpayers.

\section{REFERENCES}

Alkautsar. (2015). Analisa Potensi Dan Kontribusi Pajak Hotel Terhadap Pendapatan Asli Daerah (PAD) Kota Bukittinggi. Diploma thesis, UPT. Perpustakaan Unand.

Andayu, B.V.D. (2015). Pengaruh Sikap Wajib Pajak terhadap Kepatuhan Wajib Pajak (Studi pada Wajib Pajak Orang Pribadi yang melakukan usaha dan terdaftar di Kantor Pelayanan Pajak Pratama Malang Utara). Sarjana thesis, Universitas Brawijaya.

Arikunto, S. (2005). Manjemen Penelitian Edisi Revisi. Jakarta: Rineka Cipta.

Bagozzi, R. P., \& Baumgartner, H. (1994). The evaluation of structural equation models and hypothesis testing. Principles of marketing research, 1(10), 386-422.

Bank Indonesia. (2016). Laporan Tahunan 2016. Available at https://www.bi.go.id/id/publikasi/laporantahunan/bi/Documents/AR2016 20170622.pdf 
Byrne, B.M. (2001). Structural Equation Modeling with AMOS: Basic Concepts, Applications, and Programming. Mahwah, NJ: Lawrence Erlbaum Associates.

Byrne, B. M. (2016). Structural equation modeling with AMOS: Basic concepts, applications, and programming. Routledge.

Ditjen Pajak. (2015). Siaran Pers Ditjen Pajak Ajak 10.900 Pengguna Faktur Pajak Fiktif Manfaatkan TPWP 2015

Available http://www.pajak.go.id/sites/default/files/d7//Siaran\%20Pers\%20Ditjen\%20Pajak\%20Ajak\%2010.900\%20 Pengguna\%20Faktur\%20Pajak\%20Fiktif\%20Manfaatkan\%20TPWP\%202015.pdf (Accessed 18 Agustus 2018)

Gunadi. (2005). Akuntansi Pajak. Jakarta: PT. Gramedia Widiasarana.

Febianti, S.K. (2015). Pengaruh Kesadaran Wajib Pajak Orang Pribadi Dan Sanksi Denda Terhadap Kepatuhan Pembayaran Pajak Penghasilan ( Studi Survei Pada Kantor Pelayanan Pajak Pratama Garut). Skripsi. Fakultas Ekonomi Universitas Widyatama.

Fikri, A.H.M. (2012). Kepatuhan masyarakat membayar pajak rendah. Diakses dari www.garutkab.go.id

Hair Jr, J., Sarstedt, M., Hopkins, L., \& G. Kuppelwieser, V. (2014). Partial least squares structural equation modeling (PLS-SEM) An emerging tool in business research. European Business Review, 26(2), 106121.

Indah, R. (2016). Pengaruh Penghasilan Tidak Kena Pajak (PTKP) Terhadap Tingkat Kepatuhan Wajib Pajak Pengusaha Bebas. Sarjana Thesis, UIN Maulana Malik Ibrahim Malang.

Jamin, S. (2001). Analisis Kepatuhan Wajib Pajak Sebelum dan Selama Krisis Ekonomi Pada KPP di Wilayah Jawa Tengah dan DI Yogyakarta. Universitas Diponegoro: Tesis Program Pasca Sarjana Magister Sains Akuntansi.

Jatmiko, A.N. (2006). Pengaruh Sikap Wajib Pajak pada Pelaksanaan Sanksi Denda, Pelayanan Fiskus, dan Kesadaran Perpajakan Terhadap Kepatuhan Wajib Pajak Studi Empiris Terhadap Wajib Pajak Orang Pribadi di Kota Semarang. Universitas Diponegoro: Tesis Megister Akuntansi.

Kline, R. B. (2004). Beyond Significance Testing: Reforming Data Analysis Methods in Behavioral Research. Washington, DC: American Psychological Association.

Leba. (2016). Dampak Pelaksanaan Kebijakan Penghapusan Sanksi Pajak terhadap Kepatuhan Wajib pajak Orang Pribadi. Studi Kasus di KPP Pratama Wilayah Kanwil Direktorat Jendral Pajak Daerah Istimewa Yogyakarta.

Narbuko, C., \& Achmadi, A. (2012). Metodologi Penelitan. Jakarta: Bumi Aksara.

Nurmantu, S. (2003). Pengantar Perpajakan. Jakarta: Granit.

Pramudito, S.P. (2015). Direktur Jenderal Pajak Kementrian Keuangan. Kementerian BUMN Dorong Evaluasi Aset. Diakses di http://koransindo.com

Rahayu, S.K. (2010). Perpajakan Indonesia. Yogyakarta: Graha Ilmu.

Rahman, A. (2010). Administrasi Perpajakan. Bandung: Nuansa.

Santoso, S. (2001). SPSS Versi Mengolah Data Statistik Secara Profesional. Jakarta: PT. Elex Media Komputindo.

Sari, D.N. (2014). Pengaruh Pelaksanaan Self Assessment System, Pengetahan Pajak dan Pemeriksaan Pajak Terhadap Kepatuhan Wajib Pajak dalam Menyampaikan Surat Pemberitahuan. Skripsi. Fakultas Ekonomi. Universitas Bung Hatta.

Sugiyono. (2009). Metode Penelitian Kuantitatif, Kualitatif dan R\&D. Bandung : Alfabeta.

Sumardiyanti, V.A., \& Suryo, A. (2006). Perpajakan Indonesia. Yogyakarta: UPP AMP YKPN.

Supadmi. (2010). Kepatuhan Memenuhi Kewajiban Pajak Secara Sukarela Merupakan Tulang Punggung Dari Self Assesment. http://ejournal.unud.ac.id/abstrak/ok\%20supadmi.pdf.

Supriyanto, E. (2011). Akuntansi Perpajakan. Graha Ilmu. Yogyakarta.

Suyatmin. (2004). Pengaruh Sikap Wajib Pajak Terhadap Kepatuhan Wajib Pajak Dalam Pembayaran Pajak Bumi dan Bangunan Studi Empiris di Wilayah KP. PBB Surakarta. Universitas Diponegoro: Tesis Program Pascasarjana Universitas Diponegoro.

Widayati, \& Nurlis. (2010). Faktor-Faktor Yang Mempengaruhi Untuk Membayar Pajak Wajib Pajak Orang Pribadi Yang Melakukan Pekerjaan Bebas Studi Kasus Pada KPP Pratama Gambir Tiga. Proceeding Simposium Nasional Akuntansi XII. Purwokerto. 